daily corrects some 40,000 private and public clocks, was efficiently maintained throughout the year with an average error of only 0.15 second.

Radiant Point of the 1903 Leonid Shower.-During a watch extending from $13 \mathrm{~h}$. to $17 \mathrm{~h}$. on November $\mathrm{I} 4$, 1903 , two observers at the Ladd Observatory, Providence, Rhode Island, counted 44 meteors, of which 20 were. Leonids. Eighteen of the latter were plotted on a chart, and gave a

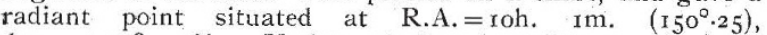
dec. $=+2 \mathrm{I}^{\circ} \quad 4^{\prime}$. Under similar conditions in IgOI (November I4, I2h. 35m.-I7h. 3om.) 9r Leonids were charted. This difference, not being due to unfavourable meteorological conditions, indicates a diminution in the intensity of the shower for the epoch observed (Popular Astronomy, January)

Comparison-Star Photographs for Minor Planets, \&c. - In No. I, vol. ii., of the Publications of the Astrophysical Observatory, Konigstuhl-Heidelberg, Prof. Max Wolf publishes a catalogue of the photographs taken by $\mathrm{Mr}$. Dugan during the period $189 \mathrm{I}-1896$.

The catalogue contains plates of the regions which were photographed for the purpose of obtaining comparison stars for minor planets, comets and variable stars, and for each plate it gives the date, the objective used, the region photographed, the designation of the guiding star, and the length of the exposure given.

\section{NAUTICAL EDUCATION IN JAPAN.}

A COPY of the prospectus of the Nautical College at Tokio has been received from the director of the college, together with some particulars as to the position of the mercantile marine in Japan. So much attention is being directed to that country at the present time that the following facts are of interest in showing the provision made for the scientific training of officers and men. Before entering into the details of nautical education in Japan, a glance at a statement of the increase of tonnage and number of seamen up to the end of 1902 is instructive.

In the year 1897 the total tonnage of the vessels in Japan did not exceed 400,000 tons, including both steamers and sailing ships; but with the expansion of national industry the number and tonnage of the vessels rapidly increased, and by the end of 1902 the tonnage amounted to 934,961 tons, out of which 605,122 tons relate to steamers and 329,839 tons to sailing ships.

At present, of the skilled officers-inates and engineers - of certified ability handling these ships, Igor are Japanese and $33 \mathrm{I}$ are foreigners. As such is the case, the necessity of training good seamen is urgently felt, and the Japanese Government is paying much attention to nautical education.

In Japan the only organised establishment for training higher seamen is the Nautical College at Tokio. It is attached to the Department of Communications, and the institution was first founded in 1875 by the Mitsubishi Company, but it was transferred to the Japanese Mail Ship Company. In 1885 the school was transferred to and reorganised by the Government, and has grown since up to the condition of the present Nautical College.

The college educates youths destined to become officers of the mercantile marine, that is, it instructs them in theory and practice of matters pertaining to the higher seaman's profession. The course of study is divided into two departments, namely, the department of navigation and that of engineering.

The cadets of both departments are enlisted in the navy during their college life and even after their graduation, and as they are to be appointed as naval officers they have to observe the general laws of the navy.

The classes and curriculum of the navigation department are as follows:-

$$
\text { : } \begin{array}{ll}
\text { Se } \rightarrow \text { manship (theoretical). } & \text { Law. } \\
\text { Seamanship (practical) } & \text { Chemistry. } \\
\text { Physics. } & \text { Commercial geography. } \\
\text { Mathematics. } & \text { Foreign language. } \\
\text { Modern Japanese and } & \text { Military drill. } \\
\text { Chinese languages. } &
\end{array}
$$$$
\text { No. I788, VOL. 69j }
$$

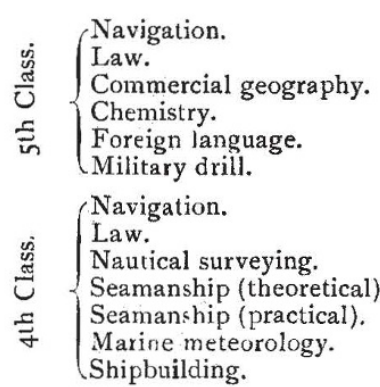

Navigation.

Nautical surveying.

递 $\left\{\begin{array}{l}\text { Practical instructions in } \\ \text { seamanship. }\end{array}\right.$

己ु Mathematics.

Economics.

Marine meteorology.

$\left.\begin{array}{l}\begin{array}{l}\text { is } \\ \text { जavigation. } \\ \text { Marine meteorology. } \\ \text { Shipbuilding. } \\ \text { Economics. } \\ \text { ज. } \\ \text { Foreign language. } \\ \begin{array}{c}\text { General principles of steam } \\ \text { engine. }\end{array}\end{array} \\ \text { Ist } \\ \text { Class. }\end{array}\right\}$

Seamanship (theoretical).

Seamanship (practical).

Physics.

Mathematics.

Modern Japanese and

$\{$ Chinese languages.

$\{$ General principles or

steam engine.

Physics.

Foreign language.

Mathematics.

Nautical hygiene.

Military drill.

Seamanship (theoretical). Shipbuilding.

General principles of Law.

steam engine.

Practical surgery.

Military drill.

Law.

Seamanship (theoretical).

Seamanship (practical).

Military drill.

Apprenticeship in far-seagoing vessels.

In this department, navigation, theoretical and practical seamanship, nautical surveying, marine meteorology, law and shipbuilding are regarded as principal studies and the others as auxiliaries.

On entering, the cadets are placed in the sixth class, and are promoted to a higher class every half year; they are instructed in the college class rooms until they advance to the first class, when they are taken to the gunnery schoo at Yokosuka to be instructed in gunnery for about six months. Then they are to serve their terms of apprentice. ship on board several vessels for two and a half years,

\begin{tabular}{|c|c|c|}
\hline 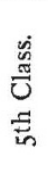 & $\left\{\begin{array}{l}\text { Steam engine. } \\
\text { Drawing. } \\
\text { Mechanics. } \\
\text { Chemistry. } \\
\text { Foreign language } \\
\text { Military drill. }\end{array}\right.$ & $\begin{array}{l}\text { Steam boiler. } \\
\text { Shop practice. } \\
\text { Physics. } \\
\text { Mathematics. } \\
\left\{\begin{array}{c}\text { Modern Japanese } \\
\text { Chinese languages. }\end{array}\right.\end{array}$ \\
\hline & $\left\{\begin{array}{l}\text { Steam engine. } \\
\text { Drawing. } \\
\text { Mechanics. } \\
\text { Chemistry. } \\
\text { Foreign language. } \\
\text { Military drill. }\end{array}\right.$ & $\begin{array}{l}\text { Steam boiler. } \\
\text { Shop practice. } \\
\text { Physics. } \\
\text { Mathematics. } \\
\left\{\begin{array}{c}\text { Modern Japanese } \\
\text { Chinese languages. }\end{array}\right.\end{array}$ \\
\hline$\frac{5}{0}$ & $\left\{\begin{array}{l}\text { Electricity. } \\
\text { Shop practice. } \\
\text { Mathematics. } \\
\text { Military drill. } \\
\text { Steam engine. }\end{array}\right.$ & $\begin{array}{l}\text { Drawing. } \\
\text { Mechanics. } \\
\text { Foreign language. } \\
\text { Steam boiler. }\end{array}$ \\
\hline
\end{tabular}
thus taking five and a half years to complete their education.

In the department of engineering, the classes and curriculum are as follows :-

Ist Apprenticeship in engineering practice and in the Class. \{ management of steam engine.

In the engineering department, steam engine, steam boiler, electricity, drawing and shop practice are regarded as principal studies and the others as auxiliaries.

On entering the department each and every cadet is first placed in the fifth class, and he can rise to a higher class at the end of every six months. He is instructed in the class rooms, as is the case with the cadet of the navigation department. When he advances to the first class he is placed in some factory or yard to receive practical training for two years, and is then taken on board several vessels to serve his term of apprenticeship in engineering for a year, thus taking five years to finish his course. 
It is a great incentive for the students that the college sends abroad those graduates who are of promising ability and of good character for the completion of their education.

Any boy above fifteen and below twenty-one years of age is admitted to the college after passing the entrance examinations. The graduates of the Government public or private middle schools, which are acknowledged by the Minister of Education to be on equal footing with the public middle schools, are admitted to the college without entrance examination on their scholarship, provided they receive satisfactory reports as to ability and character from the respective schools where they have graduated.

The cadets are of two kinds, those who are supported by loans from the Government or from some mercantile corporations, and those paying their own expenses. Such students of good character and ability as are deemed by the college authorities to be worthy examples to follow are treated as honorary students, and they are freed from their expenses.

The teaching and administrative staffs of the college comprise sixty-six members, and the total number of cadets undergoing instruction at the college, in workshops, and on board ships is 515 .

To practise the cadets in making knots, seigings, splices, hitches, bends, bending and unbending, making and taking in sails, sending up and down yards and spars, a training ship named the Meiji Maru is moored in the basin belonging to the college, where the cadets are drilled after their morning class lessons are over. They are also drilled in boating, sailing and steering. The Meiji Maru was built at Glasgow, being of $1037 \cdot 20$ tons gross and 457.46 net tons; length 242 feet, breadth $29 \cdot 25$ feet, depth $2 \mathrm{I} \cdot 50$ feet. The college owns another sailing vessel named the Kotonoo Maru, used as a training ship. This was built in London, being 825.32 tons gross and 775.62 net tons; length 161.85 feet, breadth 17.65 feet. The ship is employed in coasting the neigh wouring seas.

A large sailing vessel named the Taisei Maru, of more than 2000 tons, is now in course of building ${ }^{n t}$ the Kawasaki Dock in Kōbe, and when finished it will be used as a training ship in navigating not only to the different ports in Japan, but also to those of Europe, America, Australia, \&c.

Besides the Government Nautical College, the Nippon Kaiin Ekisaikwai (Japan Sailors' Home) is to some extent contributing toward the training of higher seamen. The association has branch offices at Tokio, Kōbe, and Nagasaki, where a number of ordinary seamen of some experience are instructed in order to prepare themselves for the examinations to obtain the higher seamen's licenses.

Other public institutions for training higher seamen are the nautical schools at Hakodate, Hokkaido; Oshima, Yamaguchiken; Ochigori, Ehimeken; Mitoyogốri, Kagawaken ; Toba, Miyeken; Sagagori, Saga; Toyoda, Hiroshimaken. In these institutions navigation and engineering courses are offered. The institutions are open to boys who have finished their four years' course at high elemen tary schools, and to those who are regarded upon examination as of equal ability. The course is about six and a half years. the lessons being as follows :-

Navigation $\begin{cases}\text { Moral code. } & \text { Reading. } \\ \text { Composition. } & \text { Mathematics. } \\ \text { Physics. } & \text { Chemistry. } \\ \text { Geography. } & \text { Foreign language. } \\ \text { Drawing. } & \text { Gymnastics. } \\ \text { Elements of surgery. } & \\ \begin{array}{l}\text { General principles of } \\ \text { marine meteorology and shipbuilding. } \\ \text { Principles of mercantile marine business. }\end{array}\end{cases}$

Engineering $\left\{\begin{array}{l}\text { Mechanics. Applied Mechanics. } \\ \text { General principles of electricity. } \\ \text { Department. } \\ \text { General principles of shipbuilding. } \\ \text { Principles of mercantile marine business. }\end{array}\right.$

The graduates of the institution mentioned are required to take the examination for higher seamen, and when they successfully pass it they are made deck-officers or engineers, but the graduates of the Nautical College are granted seamen's certificates without examination.

No. I 788 , voL. 69]

\section{THE SANDING-UP OF TIDAL HARBOURS.}

$\mathrm{T}$ the meeting of the Institution of Civil Engineers on A January $26 \mathrm{Mr}$. A. E. Carey read a paper on "The Sanding-up of Tidal Harbours."

The object of the paper was to indicate the effects of sanding-up in harbours situated (I) where no river debouches, and (2) at the mouths of rivers or estuaries. Of the three channels to the Port of Ostend one is now abandoned, and the other two are kept clear by the annual dredging of $95^{\circ}, 000$ cubic metres. Similarly the Port of Boulogne requires the annual dredging of 535 , ooo cubic metres. Mr. Carey considers that dredging is the only satisfactory expedient for conserving working depths at the mouths of sand-threatened harbours. Littlehampton is an instance of a permanent harbour at a river-mouth, but the entrance is almost dry at low water. The obliteration of Cearà Harbour, Brazil, a work which oocupied ten years and cost more than $400,000 l$., provides an instance of the extinction of a harbour by sand. From a study of the various stages in the construction of the harbour of Madras, it appears that the changes in the contour of the coast which resulted from the first two years' working included a progressive shoaling of the entire area of the harbour up to the original $7 \frac{1}{2}$-fathom line. In the opinion of the mixed commission appointed by the Indian Government in 1883 , unless the opening of the harbour as designed were closed, and a new opening to the north-east substituted, the harbour would prove valueless as a shelter for shipping.

Referring to the harbours of Denmark, Mr. Carey said that on the west coast the only harbour is that of Esbjerg, and, with this exception, fishing-boats have no shelter except the mouth of the Limfjord. At Hirtshals a Government harbour was projected at a cost of $550,000 l$., and the works were started in 1879. The work is now sanded-up and abandoned, except that the pier has since been prolonged. The utilisation of the Ringkjöbingfjord was advocated, and plans were submitted of an isolated harbour connected by viaducts with the shore at Sandnaæshage, a favourable spot owing to the depth of water there, and the protection of an outlying reef. The Danish Government has now determined on the construction of a small harbour at Skagen, and of two isolated moles, respectivery at Hanstholm and Vorupör. In view of the precarious nature of tidal harbour work, a departure from established practice is called for. Harbours of refuge have a limited range of utility, unless in land-locked positions. In a number of instances it would be practicable by means of piled structures to create shipping facilities which would meet reasonable requirements, and come within the resources of local authorities, also avoiding the permanent expense of dredging. Such structures would, however, have to be carefully designed, especially in relation to their height, cranage, and the moorings for vessels frequenting them.

\section{UNIVERSITY AND EDUCATIONAL INTELLIGENCE.}

OXFord.-The following appointments of examiners for 1904 and 1905 have been approved:- In the final honour school of chemistry, Mr. Herbert B. Baker; in the preliminary examination in physics, Mr. Robert E. Baynes; in chemistry, Mr. George B. Croushaw; in botany, Mr. A. C. Seward, F.R.S.

It has been resolved in convocation to confer the degree of D.C.L., honoris causa, upon Mr. Henry Wilde, F.R.S. and of M.A., honoris causa, upon Mr. J. J. Manley, curator of the Daubeny Laboratory, Magdalen College.

A sum of $1200 l$. has been offered to the university by $\mathrm{Mr}$. Philip Francis Walker for the purpose of founding a studentship for original research in pathology. The studentship will not be confined to members of the University of Oxford. Elections to it are to be made by a board consisting of the Vice-Chancellor, the regius professor of medicine, the Waynflete professor of physiology, the president of the Royal College of Physicians, and Mr. Philip F. Walker. It is not to be awarded by the result of a competitive examination. The studentship is to be tenable for three years, and of the annual value of $200 l$.

In order to avoid the overlapping of practical work in 